\title{
Literal perspectivism in the Colombian Amazon
}

\begin{abstract}
The purpose of this article is to contribute perspectivism theory of Viveiros de Castro which is based on ethnographic information. A constructive criticism most based in conversations and interviews with indigenous people through an observation participation process of living in two communities in Colombian Amazon. I will refer to a jaguar who become man, United Nations programs in Colombia, under the sea's non-humans, substances purposes and religion, with these ethnographic information, two physical axes, time and space, could be added to perspectivism theory and for each ontology.
\end{abstract}

Keywords: political ecology, perspectivism, ontologies, nasa, ticuna, huitoto, Amazon
Volume 2 Issue 3 - 2018

\author{
Ivan Carroll Janer ' \\ History, Environment and Politics group of COLCIENCIAS \\ Correspondence: Ivan Carroll Janer, Mexico Ph D Social \\ Anthropology, ENAH, México City. MSc Amazon Studies, UNAL, \\ Colombia. Member of History, Environment and Politics group \\ of COLCIENCIAS A Category, Email iecarrollj@unal.edu.co
}

Received: May 16, 2018| Published: June 18, 2018

\section{Methodology}

I explain ethnographic data ${ }^{1}$ for two reasons: people trust on me and I have met them more than ten years ago. ${ }^{1}$ So, some of them see myself as a friend not as a researcher and I saw them as friends more than a subjects. In that way, ${ }^{2}$ we found a comfortable moment to have a conversation. I came back to Colombian Amazon as a Mexican $\mathrm{Ph} . \mathrm{D}$. Candidate in 2016 and then returned as a Mexican Ph.D. in 2017 beginning of 2018. During this first period I lived in a huitoto community called Numeira Naimeku Iburu that means Sweet yard science. Yard is located in the rear part of a house where they have a maloka ${ }^{2}$ to make mambe ${ }^{3}$ of coca.

At the end of 2017 and beginning of 2018 I lived in Macedonia, ${ }^{3}$ an evangelist tikuna ${ }^{4}$ community in the Amazon River. I arrived first time to huitoto community as tourist guy in 2005 , before I became a local student, and then I arrived to ticuna community when I met a Colombian anthropologist, Ana Buitrago, ${ }^{4}$ who became mother of my son. She had written an oral history of Macedonia ${ }^{5}$ in her master thesis. I have to recall these people remembered your face, and once you stayed with them they knew in some way you will come back someday. In some way, time, trust and reciprocity are three reasons to find an ethnographic data.

Also, perspectivism theory is based on ethnography information but only an ethnography data matters to discuss, and this ethnographic data came out from all the spectrum of information. I put more attention in what they are telling me literally and not try to have metaphorical interpretation. What will happen if animism is not only metonymic but literally?

\section{Eye of the jaguar and human being}

During chontaduro's harvest celebration, people (men, women,

${ }^{1}$ See Cáceres Galindo, 1998.

${ }^{2}$ There are two kinds of maloka. One, is built in the yard of the house and other is built in a common area is much bigger. A maloka, small or big, is surrounding by coca plants, roof is made with Karana palm supported by strong tree trunks. Inside there a fire place and basics instruments to prepare mambe.

${ }^{3}$ See Londoño, 2001.

${ }^{4}$ See Zárate, 1998

${ }^{5}$ See Buitrago, 2007. ancient and children) were gathering together inside a maloka. When they were dancing, maloka's owner decided to take his shotgun and to go outside to hunt an animal in order to bring more food and to continue celebration. But, his friends insisted him do not to go outside because it was not an appropriate moment ${ }^{6}$ to hunt. Unfortunately, he didn't pay attention to them and decided to go outside. He was holding in one hand a light to see eyes of his victim, and in the other hand, at the same time, he was holding his gun. At the moment he saw an animal eye, he made a shot. He killed a man instead an animal, but not any man, he killed his neighbour, a nearest maloka's owner from a different ethnic group. He was arrested in prison, and in his version to local authorities he was saying he saw the eye of an animal when he lighted him. So, he was at the beginning happy because he hunted an animal but when he arrived to see its body, sadly the body was not of an animal was a body of a human being.

For authorities and people it came obvious that some issues caused the unfortunately episode, he was drunk, maybe mixing chontaduro with cachaza. But, what will happen if liqueur do not appear in a similar case? In other words, we are talking here about people who become animals, or animals who become people. What will be the argument of apprehension of a person who said he killed an animal or maybe a non-human but not a human being? If he saw and shut down an animal but appeared a human being, has to be a perspective problem that has not be included it in Viveiros de Castro theory.

In other similar cases, man dissertation is about he made a shotgun when he was looking to a jaguar. But when they saw animal cadaver appeared to be a man.

\section{Colonization and decolonization}

When an indigenous said "our blood is taken away to make airplanes sound less loud". ${ }^{2}$ Do we have to understand it literally? I was studying my Master when Salima Cure presented her thesis about a rumor called it head-hunters. Cure finished her Ph.D. in Italy while I was studying mine in Mexico, but we have continued thinking and

\footnotetext{
${ }^{6}$ Usually exist a preparation to hunt an animal in the forest. A man do not take a shower, do not perfume himself and he has a natural odor. For some indigenous group, for example airopai or secoya, menstruation affect directly an odor man and could damage a hunt day (Belaunde, 2005).
} 
discussing about this.

In 2016, I had a meeting in Human Rights Office of United Nations in Colombia, I went with an ancient huitoto, his son, and I as a researcher. At the meeting, I said we (academic researchers) and they (indigenous) are worry about head-hunters. Some person from the Office answered me, you are talking about a genome program of United States. There was a silence surround this meeting, and I could not continue talking or asking questions about the content of this mysterious program. He didn't explain me about the content of the program, but we started to pay more attention about comments in a literally way, because before this meeting we were trying to understand indigenous words metaphorically. I was corroborating as a social scientist, a 10 years data from indigenous, and in some way we knew the content of the program because they told us everything literally.

In this year, 2018, United Nations office in Colombia is trying to go inside nasa's ethic communities with drones to expand territory control. The issue is that some nasa went to University, some of them to Universidad Nacional de Colombia, sharing critical and reflexive discussions with classmates and teachers in the same classrooms, about contemporary and complex issues through an analytic historical approach. Furthermore, they understand divergence intentions in a globalization world and a decolonization process, ${ }^{7}$ so they have denied oil wells exploitation in their territories to Ecopetrol, the biggest entreprise in Colombia, and also to other oil companies. Constitutionally, Nation-state is the owner of oil and of all the resources under the land, but nasa people resist for their territory vision and prevent exploitation.

Also, nasa community have denied to Nation-state government a drones program to take videos and photographs of their territory, other big example of territory resistance. But First world colonization always want to have the possibility to control Third world territory. ${ }^{8} \mathrm{~A}$ new proposal from United Nations office in Colombia is to use solar energy as a development program to rural communities but putting a GPS in solar panels or in batteries to finally have this control.

For some Mesoamerican and Andean ethnic groups there are an animism ontology relation with non-humans, as for example, mountains, lakes, rivers, and even some specific animals. In some way, they have a reciprocity manner to answer to these non-humans, while transnational company has a rapacity relation with these nonhumans.

For Phillipe Descola ${ }^{5}$ all populations in time and space have four ontologies in order to establish a relationship with non-human beings, such as: naturalism, analogism, totems and animism. Even if in some population is difficult to classify, Descola proposed a possible combination of them. ${ }^{5}$ In the same way, Martinez Alier mentioned there are only two ways to make an exchange with a non-human being, there are: rapacity and reciprocity. Universe resources are finite, so in reciprocity manner people have to return its favor or givens in order to maintain energy particles which has taken away from non-humans. ${ }^{6}$

In Mesoamerican population, animism is one way to establish social relations with non-humans. ${ }^{9}$ In other possible coexisting world, a transnational establish "naturalism relations". ${ }^{7}$ Also, a rapacity ${ }^{7}$ See Escobar, 2011.

${ }^{8}$ See Palacio, 2011.

${ }^{91} \mathrm{n}$ a development context of business administration could be an economical resource. relation, because they do not make an exchange or gave something back to non-human. But at this moment, transnational social programs are including to improve education and health programs into communities, so in some way this determine not at a hundred percent of rapacity, because transnational is giving something back to people who live beside a non-human. ${ }^{8}$ I suggest a gradually rapacity, not complete it as mentioned by Martinez Alier, because in some way exist compensation process, this means a partial rapacity. Decades ago, oil well enterprises extracted resources and did not make any compensation process to local population, but today this is focusing as a social responsibility program that have to exist in every contemporary company.

Transnational companies has one argument, development. While, to local population who has lived in the territory, has a different way to live and to relate with the environment, observe and perceive development as a rights aggressive. Also, transnational companies' culture or behaviour goal's is to have the maximum monetary utility in a shortest possible time. For this reason, their employers receive good salaries, above average with social benefits. In this way, employers observe local population as an obstacle to obtain the main objective, that is, company's (shareholders) benefit. Also, shareholders and employers do not have a negative perspective when they affect natural resources, they have a positive vision about development. ${ }^{9}$ Finally, people inside a company culture is indifferent to what happen to local population because they are worry about their own daily problems in the company and in their own families.

Other ethnic group in Colombia, koguis, which some of them, also have studied at universities not only publics as Universidad Nacional de Colombia, also privates, like Universidad Externado, are planning to install solar panels in their community. First, in their chemical laboratory and then in their library. They produce natural cleaners using vegetables and fruits as raw materials that buy from peasants that live near them. So, they are building a productivity chain that will compete in a traditional market. Also, New Age movement came with this idea of buy natural products, so koguis will become a prospective organic market not only local but also international. They had ecotourism in Tayrona National Park but at the end, they understood that tourists not only brought money but also problems especially if their only purpose is to consume drugs in a paradise environment. This great idea of solar energy will be a problem if foundations or enterprises, promoting by United Nations office in Colombia want to have territory control by GPS or other available technology. ${ }^{10}$

\section{Under the water ontology}

Viveiros de Castro perspectivism theory involves clearly a world on the ground, in the forest, but it not seems clear on the river. Viveiros de Castro has talked about a perspective surrounding animals on the ground but in the water it seems to happen quit similar. I have had sessions with Professor Juan Alvaro Echeverri ${ }^{10}, 11$ and he told me: "dolphins, anacondas, also have their malokas under the water". But people do not talked about animals they are talking about other kind of people, and in this case we are going to concentrate in two: dolphins and Mermaids.

A few years ago, I heard something unusual about a child who had drowned on a water ravine connected it with Amazon River. ${ }^{12}$ After that, ancients had a council and spoke with his mother; they decided ${ }^{10}$ Professor Universidad Nacional de Colombia Sede Amazonia, Director
IMANI 
to tell her in front of the community that her son was charmed by nonhumans living under the river. A similar world but under the Amazon River.

People told me a whirl is caused by pink dolphins, anacondas and Mermaids and they were agreed that on the Amazon River water always got turbulent. In a ticuna community, a 19 years old boy was drinking beer with his friends. When they have drunk all the beer, they decided to cross to the other side of the Amazon River to buy more beer in other community, but when he was rowing at the front of the little boat, a whirl came out on the river and he felt down on the water and his body could not be found. ${ }^{13}$

Even though, Amazon River is one of the biggest rivers in the world, his parents decided to ask a Shaman ${ }^{11}$ for help in order to take their son out from the water. At that moment, their son has spent 15 days under the water. So, when Shaman arrived several members of the community gathered together and stared at him. As usual, Shaman started with his prayers, his particular ceremony, and his way to make contact with non-humans. Suddenly, this boy came out from the river, but his skin had a pale color and he was cover of some leaves. In some way, has been two weeks under the water, his body change in some way to be able to breath under the water. But this boy came out from the water very savage and bit Shaman's arm. After that, he came back to the water. ${ }^{14}$

After a while, Shaman told his parents it will be necessary to come back with five more Shamans in order to convert this non-human boy in a human boy again. Shaman mentioned, under this water exist a mother Mermaids who has six Mermaids daughters and one of these daughters captured this boy for pleasure. He has changed physically by under water's non-human. ${ }^{15}$

Shaman said he will need to blow up with tobacco boy's head to return his body as it was before. I identified importance of body and not of soul, because soul or spirit is an occidental construction that does not exist for pre-Hispanic indigenous. To return his original body, Shaman mentioned it is necessary five Shaman's to gather together in front of the river.

This non-human event became an everyday conversation and people got used here to talk about these events but between them, it is not usual to tell these stories to foreign people or tourists. These people, living along river side of Amazon River talk without get surprised about relations and events with non-humans.

\section{Time and space using substances}

But what will happen to Descola proposal of ontologies if is expanded by including consumption of substance? Indigenous have had different ways to travel in time and space in order to establish reciprocity relations, bringing health or illness to people or even to cause a possible death. An ancient mentioned, "it is not necessary to travel physically, body do not need to go to one place to another". Indigenous knew before first metro was built that in big cities people will move themselves inside of some kind of worms.

Anthropologist researchers of Amazon area are agreed envy are very harmful and could cause illness and death. Tabac, ${ }^{12}$ coca and yaje are used to materialize this envy and cause illness or death. In huitoto

${ }^{11}$ If a Shaman is taking out of its context will be medical diagnostic as mental

illness. See Mauss, 1979.

${ }^{12}$ See Echeverri, 2002 community, each yard home concentrate power. This could be used to desire good or bad things, but often this power is to harm other people.

A ceremony with substances could improve health or provoke illness to a person in other place. Human Rights Office of United Nations in Colombia know that indigenous could cause death to other humans without any physical contact. In a meeting in Bogota, paradoxically inside an office with too much security, a huitoto ancient ${ }^{13}$ were talking about how yukuna first governor had betrayed his own people and how he will be punished. This governor, Manuel Carebilla, was the first indigenous Colombian state governor who was corrupted and has to be 14 years in prison. In that meeting, this huitoto ancient mentioned people from Mirití Paraná began to work in his punishment. It will not begin immediately, it will start when finish his time in jail. For this reason is what I mention time, because they have the possibility to change a destiny of one person.

In Macedonia community there was a woman of miraña's ethnic, who was a teacher of Francisco Orellana's school, the only school of the community. She discovered some ticuna's people of the community were stolen money resources of school designated to materials for children education. One day, she was going inside her home but in front of the door on the floor, there was a death fish. She lift it up with her hand and throw it away. Next day, she became very illness. In a week, she died. Antero, evangelical pastor, prayed for her when he came to visit her but at the end she died. People told me, "her body smelled rotten and worms came out from her body".

Descola propose in some cultures combinations or hybrids to classify some ontologies. ${ }^{14}$ I suggest Macedonia as a particular community on the Amazon River because people dissertation combine religion and non-humans, in other words syncretism of evangelism and animism.

Animism is an ontology defined by social relations between human and non-humans. This mean, relations between nature and society are social relations, while, in naturalism, relations between human and non-humans are natural, is an inverse axiom, relations between nature and culture are naturals. ${ }^{16}$

In this way, terms change from the look we are talking about, for example, from "nature" to "environment" implies an anthropocentric and aristotelic view. ${ }^{5}$ These means, in a business administration and capitalism context, non-humans became "natural resources" that have to be exploited base in a naturalism ontology.

\section{Religion and perspectivism}

I was waiting a boat transportation in Leticia Port to go to Macedonia (50 kilometer east by Amazon River to Iquitos direction), while having a little conversation with a woman told me about the tragically death of Antero Leon. Antero was an ancient, one of community and school founders. I called him professor as other people do because he taught ticuna language and with a linguistic group elaborated an alphabet to distinguish between guttural and nasals sounds. Staying in a ticuna community and listen to people talk is feel to be in an Asian region.

\footnotetext{
${ }^{13}$ Ancient is an older man that people from the region called him "abuelo". It means grandfather but not as a kinship relation. It has been called like this because of his wisdom and expertise using substance, such ayahuasca, coca and tabac. This man is a Shaman but do not make things for tourism purpose just to improve health of his people, while a Shaman recently is very involve with tourism receiving money from tourist to develop some activities. ${ }^{14}$ See Martinez, 2009.
} 
Ticuna is defined as cassava people $\mathrm{e}^{15}$ and do not consume tabac, coca or yajé, but even they do not use these substance as huitoto, a fish is used to harm and cause an inevitable death. Or for example, gossip is very harmful, people talk every moment and in different places in the community about someone and could make this people get headache, then illness and at the end death. ${ }^{17}$

Antero became evangelist when preachers of an American evangelism church arrived to Macedonia. He liked to predicate not only inside his community, also invited others to go outside and visit other communities. As usual, he prepared a boat travel by the river and invited more people of the community. Their little boat crashed with a big piece of wood and all passengers fell into the water.

Antero's body was found fifteen days later by a fish man floating on the river several miles He was found several miles down in an easterly direction to where the current falls. It was a "miracle" they found his body, people said.

Other "miracle", was told me by Antero's daughter in law. She was in the boat with her daughter and two grandsons, a boy and a girl. When they fell down in the water, she hold a piece of tree trunk to float. She saw her granddaughter's floating upside down, he took her hair and lifted her up. Then, she saw her mouth with white slime. She started to scream, “idear granddaughter, God loves you!”, “ $;$ God loves you!" In a couple of seconds, this girl started to breath. Then, she opened her eyes and said, "my brother is death, I saw him behind my mother's back". But her mother was floating in the water holding him with one arm. Minutes later, a tourist boat arrived and rescued the people on the water. Until this boat touched land and everybody got a little bit conscious, they realized the boy were death and her little sister said the truth. And for the people, the girl which came back from death was other's God miracle.

It was the end of the year 2017, I was having a nice conversation with one of Antero's son. He told me, after his father's death he went to the city of Leticia in order that his father pension passed to her mother, the widow. But he was informed she will have to wait two years to designate death Antero, because his body have not appeared. While his body do not appear law got notice he is disappear and do not death. His son lose hope after heard this, so he returned it to the community to tell his mother she has to wait two years. But when he arrived to Macedonia to tell this bad news to his mother, minutes before somebody told her had appeared on the river bank the body of her husband decomposed. Then, his son, crying continue talking with me and said, I carried the body of my father down the river to Leticia and then I put it in the coffin myself and I buried it. Even though, he considered it was a miracle his father's body was found fifteen days later.

In this evangelist community good events that happen are related with God's miracles and because people have too much faith in God. In some way, people coexist with non-human world and they believe in God. But young people who speak less ticuna language and want to be more enrolled with city modern staff believe too little in nonhumans.

When people believe in God and are devoted to his religion start to create a big distance with existences of other possible worlds. Ines is a local midwife of Macedonia, an ancient woman expert in traditional and natural medicine. But, recently, young woman of the community

\footnotetext{
${ }^{15}$ See also ethnography of piro in Peru which consume green banana and cassava, Gow, 2001.
}

prefer to go to the hospital in Leticia instead of her. They suggest conventional and modern treatment is better. Even though, Ines has able to turn a baby inside of a pregnant woman and help her to have a healthy birth.

Community gathered together to decided that Ines will receive a payment if she wants to stay more time in the community. But, she does not accept this payment. At the end of the meeting, I asked her, why she do not accept this payment? She answered me if she accepts it and something get wrong, she could die.

\section{Conclusion}

This article complement perspectivism theory in the Amazon by adding two physic axes to bidimensional proposal of distinction and discussion between nature and culture: time and space, both of them could be in each ontology, in order to open the possibility of a multidimensional discussion. For example, to make a distinction between nature and culture, Levi-Strauss compared body and soul between Spanish and indigenous people but without considering he was talking about of two different moments in time and space.

Anthropologist spend a lot of time in the process of interpretation of all the information obtained from indigenous and also, analyzed these spectrum of information with categories and theories. I invited with this paper to pay more attention about what indigenous people are telling us literally, because it sounds for us, not clearly and unbelievable, some events that could be caused by international programs to developing countries to have territory control, or animism ontology related with non-humans under the water.

\section{Acknowledgments}

None.

\section{Conflict of interest}

Author declares there is no conflict of interest.

\section{References}

1. Carroll Janer, Ivan E. "El mundo subacuático de los ticuna". en revista Notimani de la Universidad Nacional de Colombia Sede Amazonia. 2012;23:10-11.

2. Cure Salima. "Cuidado te mochan la cabeza. Circulación y construcción de un rumor en la frontera amazónica de Colombia, Perú y Brasil". Thesis to obtain Master in Amazon Studies. Universidad Nacional de Colombia Sede Amazonia; 2005.

3. Belaunde, Luisa Elvira. El recuerdo de Luna. Género, sangre y memoria entre los pueblos amazónicos. Lima: Fondo Editorial de la Facultad de Ciencias Sociales-UNMSM; 2005.

4. Buitrago, Ana Isabel. "Trayectorias vitales, memoria familiar y memoria histórica en Macedonia, una comunidad indigena del Trapecio Amazonico Colombiano". Thesis to obtain Master in Amazon Studies. Leticia: Universidad Nacional de Colombia Sede Amazonia; 2007.

5. Descola, Philippe. Antropología de la naturaleza. Lima: IFEA, Lluvia Editores; 2005.

6. Martínez, Isabel. "Naturaleza-Cultura: un marco de análisis para la relación persona-cosmos". An Antrop. 2009;43:69-90.

7. Echeverri, Juan Alvaro. "La naturaleza es bagazo y la humanidad almidón, visión del medio natural desde los grupos que consumen ambil de tabaco". Boletín de Antropología. Universidad de Antioquia. 2002;15(32):13-30. 
8. Echeverri, Juan Álvaro. Pueblos indígenas y cambio climático el caso de la Amazonia colombiana. Bulletin de l'Institut Francais d'Etudes Andines. 2009;38(1):13-28.

9. Escobar, Arturo. "Ecología Política de la globalidad y la diferencia". Héctor Alimonda, editor. La Naturaleza Colonizadora. Trad. Ivan Carroll. Buenos Aires: Ediciones CICCUS, CLACSO. 2011. p. 61-92.

10. Escobar, Arturo. El final del salvaje. Naturaleza, cultura y política en la antropología contemporánea. Bogotá: CEREC-ICAN; 1999.

11. Galindo Cáceres, Luis Jesús. "Etnografia. El oficio de la mirada y el sentido" In: Galindo Cáceres, Luis Jesús (editors) Técnicas de investigación en sociedad, cultura y comunicación. 1998. México: Addison Wesley Longman. p. 347-383.

12. Gow, Peter. Of mixed blood: Kinship and History in Peruvian Amazon. Oxford: Clarendon Press; 1991
13. Mauss, Marcel. Sociología y Antropología. Trad. 4a edición francesa por Teresa Rubio de Martin. Madrid: Editorial Tecnos; 1979.

14. Londoño, Carlos David. Muinane: un proyecto moral a perpetuidad. Medellin: Universidad de Antioquia; 2001

15. Palacio Castañeda German. "Suelo, subsuelo y vuelo, los previsibles desafíos ecopolíticos para la región Amazónica colombiana". In: Héctor Alimonda, editor. La Naturaleza Colonizadora. Buenos Aires: Ediciones CICCUS, CLACSO. 2011. p. 93-112.

16. Viveiros de Castro Eduardo. "Perspectivismo y multinaturalismo en la América Indígena”. Eduardo Viveiros de Castro, editor. A inconstancia da alma salvagem, Sao Paulo, Cosac. 2002. p. 345-400.

17. Zárate Botía Carlos Gilberto. "Movilidad y permanencia ticuna en la frontera amazónica colonial del siglo XVIII". Journal de la Société des Américanistes. 1998;84(1):73-98. 